\title{
Sequence analysis and mRNA expression of prolactin receptor gene isoforms in different tissues of sheep during lactation and the post-weaning period
}

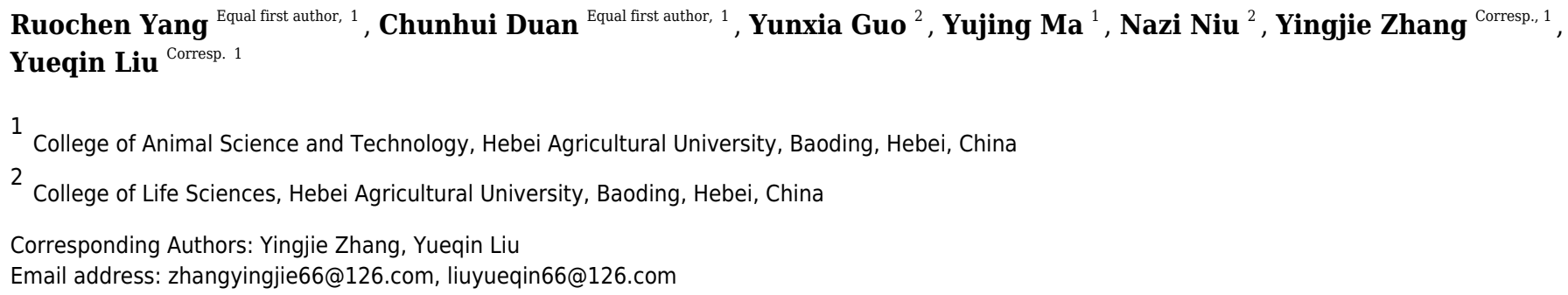

Few studies on mRNA expression of the prolactin receptor $(P R L R)$ isoforms in different tissues of sheep were reported. The objective of this study was to analyze the gene sequence and mRNA expression of PRLR isoforms in the uterus, mammary gland, ovary, spleen and lymph tissue of ewes during the lactation and post-weaning periods. Ten lactating crossbred ewes (DorperxHu sheep) with twin lambs were used in this study. Five ewes were chosen randomly and slaughtered at mid-lactation (35 days after lambing). The remaining 5 ewes were slaughtered on the $5^{\text {th }}$ day after weaning. Samples of uterus, mammary gland, ovary, spleen and lymph tissue were collected from each ewe to determine the mRNA expression of long PRLR ( $L-P R L R)$ and short PRLR (S-PRLR) by RTqPCR. The physical and chemical properties, the similarity of the nucleotides $L-P R L R$ and $S$ $P R L R$ genes and the secondary and tertiary structure of the $L-P R L R$ and S-PRLR proteins of sheep were analyzed. The results indicated that the predicted protein molecular weights of $L-P R L R$ and S-PRLR are 65235.36 KD and 33847.48 KD, respectively, with isoelectric points of 5.12 and 8.34, respectively. The secondary protein structures of $L-P R L R$ and S-PRLR are different. For $L-P R L R$ these include alpha helix, extended strand and random coils and $\beta$ turns for which the content was $16.01 \%, 21 \%, 59.55 \%$ and $3.44 \%$, respectively, whereas the secondary protein structures of S-PRLR contain only alpha helices, extended strand and random coils, comprising $18.24 \%, 30.07 \%$ and $48.99 \%$, respectively. The $L-P R L R$ and $S-P R L R$ genes of the sheep (Ovis aries) had nucleotide sequences showing much similarity among ruminants. In these sheep, mRNA expression of $L-P R L R$ and S-PRLR was highest in the uterus and differed between the uterus, ovary, mammary gland, spleen and lymph tissue. The mRNA expression of $L-P R L R$ in lymph tissue was higher during lactation than in the post-weaning period $(P<0.01)$, whereas mRNA expression of $S-P R L R$ in the uterus and the mammary gland was lower during lactation than during the post-weaning period $(P<$ 
$0.01)$. In the uterus, mRNA expression of $L-P R L R$ was higher than that of $S-P R L R$ during lactation $(P<0.01)$ but there were no significant differences $(P<0.05)$ for the other five tissues. This study that the $L-P R L R$ and S-PRLR proteins in ewes are mainly composed of extended fragments and random coils. The data also indicate that mRNA expression of $L$ $P R L R$ and S-PRLR genes varies among different tissues in sheep and is higher in the uterus than in the ovary, spleen, mammary gland and lymph tissue throughout lactation and the post-weaning period. 
1 Sequence analysis and mRNA expression of prolactin receptor gene isoforms in different

2 tissues of sheep during lactation and the post-weaning period

3

4

5 Ruochen Yang ${ }^{1,+}$, Chunhui Duan ${ }^{1,+}$, Yunxia Guo ${ }^{2}$, Yujing $\mathrm{Ma}^{1}$, Nazi Niu², Yingjie Zhang ${ }^{1, *}$,

6 Yueqin $\mathrm{Liu}^{1, *}$

7

$8{ }^{1}$ College of Animal Science and Technology, Hebei Agricultural University, Baoding, Hebei,

9 China

$10{ }^{2}$ College of Life Sciences, Hebei Agricultural University, Baoding, Hebei, China

$11+$ These authors contributed equally to this work

$12 *$ Corresponding Author.

14 Corresponding Author:

15 Yingjie Zhang ${ }^{1}$, Yueqin Liu ${ }^{1}$

16 Lokai South Street, Baoding, Hebei, 071000, China.

17 Email address: zhangyingjie66@126.com(Y.Z.); liuyueqin66@126.com(Y.L.) 


\section{Abstract}

Few studies on mRNA expression of the prolactin receptor $(P R L R)$ isoforms in different tissues of sheep were reported. The objective of this study was to analyze the gene sequence and mRNA expression of $P R L R$ isoforms in the uterus, mammary gland, ovary, spleen and lymph tissue of ewes during the lactation and post-weaning periods. Ten lactating crossbred ewes (Dorper $\times$ Hu sheep) with twin lambs were used in this study. Five ewes were chosen randomly and slaughtered at mid-lactation (35 days after lambing). The remaining 5 ewes were slaughtered on the $5^{\text {th }}$ day after weaning. Samples of uterus, mammary gland, ovary, spleen and lymph tissue were collected from each ewe to determine the mRNA expression of long $P R L R(L-P R L R)$ and short PRLR (S-PRLR) by RT-qPCR. The physical and chemical properties, the similarity of the nucleotides $L-P R L R$ and $S-P R L R$ genes and the secondary and tertiary structure of the $L-P R L R$ and $S-P R L R$ proteins of sheep were analyzed. The results indicated that the predicted protein molecular weights of $L-P R L R$ and $S-P R L R$ are $65235.36 \mathrm{KD}$ and $33847.48 \mathrm{KD}$, respectively, with isoelectric points of 5.12 and 8.34 , respectively. The secondary protein structures of $L$ $P R L R$ and $S-P R L R$ are different. For $L-P R L R$ these include alpha helix, extended strand and random coils and $\beta$-turns for which the content was $16.01 \%, 21 \%, 59.55 \%$ and $3.44 \%$,

41 respectively, whereas the secondary protein structures of $S-P R L R$ contain only alpha helices,

42 extended strand and random coils, comprising $18.24 \%, 30.07 \%$ and $48.99 \%$, respectively. The $L$ - 
$43 \quad P R L R$ and $S$-PRLR genes of the sheep (Ovis aries) had nucleotide sequences showing much

44 similarity among ruminants. In these sheep, mRNA expression of $L-P R L R$ and $S$ - $P R L R$ was

45 highest in the uterus and differed between the uterus, ovary, mammary gland, spleen and lymph

46 tissue. The mRNA expression of $L-P R L R$ in lymph tissue was higher during lactation than in the

47 post-weaning period $(P<0.01)$, whereas mRNA expression of $S$ - $P R L R$ in the uterus and the

48 mammary gland was lower during lactation than during the post-weaning period $(P<0.01)$. In

49 the uterus, mRNA expression of $L-P R L R$ was higher than that of $S$ - $P R L R$ during lactation $(P<$

50 0.01) but there were no significant differences $(P<0.05)$ for the other five tissues. This study

51 that the $L-P R L R$ and $S-P R L R$ proteins in ewes are mainly composed of extended fragments and

52 random coils. The data also indicate that mRNA expression of $L-P R L R$ and $S-P R L R$ genes varies

53 among different tissues in sheep and is higher in the uterus than in the ovary, spleen, mammary

54 gland and lymph tissue throughout lactation and the post-weaning period.

55 Keywords: Sheep; Prolactin receptor; Lactation; Post-weaning

\section{Introduction}

Prolactin $(P R L)$ is a single chain polypeptide hormone synthesized and secreted from the

anterior pituitary gland. It belongs to the prolactin/growth hormone family (Goffin et al., 1996)

and participates in various physiological processes in mammals such as reproduction, immunity

and regulation of metabolism (Freeman et al., 2000). The prolactin receptor, $P R L R$, has a central role in the $P R L$ signal transduction cascade since $P R L$ exerts its biological functions by binding to PRLR (Bignon et al., 1997). PRLR belongs to the superfamily of cytokine receptors and has 
64 both a long and a short prolactin receptor ( $L-P R L R, S-P R L R$, respectively) (Bignon et al., 1997).

65 Their genes, $L-P R L R$ and $S-P R L R$, are expressed by alternative splicing of a single $P R L R$ gene

66 (Chen et al., 2020) and they differ by the lengths of their carboxyl-terminals at the cytoplasmic

67 domains (Viitala et al., 2006).

68 Many previous studies have reported that $P R L R$ is associated with reproduction (Goffin et

69 al., 1998). In rodent ovaries mRNA expression of $L-P R L R$ is higher than that of $S$ - $P R L R$ during

70 all phases of the estrous cycle and throughout pregnancy (Clarke et al., 1993; Clarke and Lanzer

71 et al., 1993). PRLR has also been reported to be associated with immunity (Zhou et al., 2020).

72 For instance, the circulating concentration of PRL directly affects the production of $\mathrm{CD}_{\mathrm{S}}^{+} \mathrm{T}$ cells

73 (Bernichtein et al., 2010) and the role of PRL needs to be achieved by the expression of PRLR on

74 immune cells (Zhou et al., 2020). S-PRLR has been cloned in rats (Boutin et al., 1988), and L-

$75 P R L R$ is widely expressed in the muscle, liver, spleen, mammary gland and adipose tissues of

76 dairy goats (Shi et al., 2016). However, few studies on mRNA expression of the PRLR isoforms

77 in different tissues of sheep were reported. We hypothesized that the expression of $L-P R L R$ and

78 S-PRLR were different in uterus, ovary, mammary gland, spleen and lymph tissue of sheep

79 during the different physiological phases. If it does, it will be of great value for further research

80 on the function of $L-P R L R$ and $S-P R L R$ in ruminants. Therefore, the objective of the present

81 study was to analyze the gene sequence of $P R L R$ isoforms and the mRNA expression of $L-P R L R$

82 and $S-P R L R$ in the ovary, mammary gland, uterus, lymph tissue and spleen in ewes of the

83 Dorper $\times$ Hu breed during the lactation and post-weaning periods.

Materials and methods 


\section{Animals and experimental design}

The study was conducted from August to October 2018 on Weizun Sheep Farm located in the Hebei province of China. All procedures used in this study were approved by the Laboratory Animal Ethics Committee of Hebei Agricultural University (Hebei, P.R. China; permit number 2018082).

$$
\text { Total mixed rations (TMR) were formulated according to NRC (2007). Ewes were fed }
$$
twice daily, at $0700 \mathrm{~h}$ and $1700 \mathrm{~h}$, and had free access to clean water. Feed residuals were 5\%$7 \%$ of the total offered and these were removed when cleaning was carried out each day after the afternoon feeding.

\section{Ten lactating crossbred ewes (Dorper $\times \mathrm{Hu}$ sheep, 2.5 years of age) with twin lambs were} used. Five ewes were chosen randomly and euthanized in the middle (35 days after lambing) of the lactation period. The remaining 5 ewes were euthanized on the $5^{\text {th }}$ day after weaning. Samples of tissue from the uterus, mammary gland, ovary, spleen and lymph tissue were collected from each ewe after euthanized.

\section{Data and sample collection}

$$
\text { Ten ewes were deprived of feed for } 24 \mathrm{~h} \text { and of water for } 16 \mathrm{~h} \text { then killed humanely at }
$$
around $0800 \mathrm{~h}$ using electro-stunning followed by severance of blood vessels in the neck.

Samples of tissue from the uterus, mammary gland, ovary, spleen and lymph tissue were obtained within 20 minutes of death under sterile conditions by using a sterile scalpel. These were cut into $0.2 \mathrm{~cm}^{3}$ pieces and then immediately frozen in liquid nitrogen for storage until extraction of RNA for the analysis of PRLR expression. 
106

107

108

109

110

111

112

113

114

115

116

117

118

119

120

121

122

123

124

125

126

\section{Analytical procedures}

\section{Primer design}

Conserved regions were found by aligning sheep $L-P R L R, S-P R L R$ and GADPH gene sequences published in GenBank using DNAMAN. Primers were then designed from the conserved region using Primer Premier 5.0 and synthesised by Shanghai Sheng Gong Biotechnology Co., Ltd. Primer sequences and related information are as follows: L-PRLR: 5'CCCCTTGTTCTCTGCTAAACCC-3' (forward), 5'-CTATCCGTCACCCGAGACACC-3' (reverse)(120bp); S-PRLR: 5'-AAATACCTTGTGCAGATTCGATG-3' (forward), 5'AAACACAGACACAAGGCGAGA-3' (reverse)(267bp); GAPDH: 5'CTGACCTGCCGCCTGGAGAAA-3' (forward), 5'-GTAGAAGAGTGAGTGTCGCTGTT-3' (reverse)(149bp).

\section{RNA extraction and quantitative real-time PCR}

After thoroughly grinding the collected tissues in liquid nitrogen, total RNA was extracted according to the specification of TRNzol total RNA extraction kit (TIANGEN) and stored at -80

${ }^{\circ} \mathrm{C}$. Reverse transcription was carried out using a reagent kit (Takala) according to the manufacturer's instructions. The reaction mixture, $20 \mu \mathrm{L}$, consisted of $5 \times \mathrm{Mix}(4 \mu \mathrm{L}), \mathrm{RNA}(2$ $\mu \mathrm{g})$, and RNase-free water $(16 \mu \mathrm{L})$. The reaction was performed at $37{ }^{\circ} \mathrm{C}$ for $15 \mathrm{~min}$ followed by $85{ }^{\circ} \mathrm{C}$ for $5 \mathrm{~s}$; the product was stored at $-4{ }^{\circ} \mathrm{C}$.

q-PCR was conducted in strict accordance with the LC-480 PCR system instructions using Ultra SYBR Mixture (with Rox) and the following cycling protocol: $10 \mathrm{~min}$ at $95{ }^{\circ} \mathrm{C}$ followed by

40 cycles consisting of $15 \mathrm{~s}$ at $95{ }^{\circ} \mathrm{C}$ and $60 \mathrm{~s}$ at $60{ }^{\circ} \mathrm{C}$. The reaction mixtures contained $10 \mu \mathrm{L}$ 
127 Ultra SYBR Mixture $(2 \times), 0.4 \mu \mathrm{L}$ upstream and downstream primers $(10 \mu \mathrm{M})$ each, $2 \mu \mathrm{L}$

128 template and sterile distilled water to a final volume of $20 \mu \mathrm{L}$. Relative expression of the target

129 genes was calculated by the $2^{-\Delta \Delta \mathrm{CT}}$ method based on the quantitative real-time PCR results.

130 Sequencing Analysis

131 EditSeq software was used to predict the physical and chemical properties of $L-P R L R$ and

$132 S-P R L R$ in ewes, which included amino acid composition, isoelectric point and theoretical

133 molecular weight; DNAMAN software was used to analyze the similarity of the nucleotides of

$134 L-P R L R$ and $S-P R L R$. Online software was used to predict the secondary structure of $L-P R L R$

135 and $S$-PRLR proteins (https://npsa-prabi.ibcp.fr/cgi-

136 bin/npsa automat.pl?page=npsa_sopma.html) and their tertiary structure

137 (Http://www.expasy.org/swissmod/SWISS-MODEL.html).

138

139

140

141

142

143

144

145

146

147

\section{Statistical analysis}

Data were analyzed by one-way analysis of variance (ANOVA) and T-test for comparisons

(T-test was used for mRNA expression in the same tissue of the same isoform at different

periods and in the same tissue of different isoforms at the same period. One-way ANOVA was

used to analyze the mRNA expression of the same isoform in different tissues at the same

period). All calculations were performed with the SAS 9.2 software (SAS Inst., Cary, North

Carolina, USA). GraphPad prism 6.0 software was used to make the chart. Differences were

considered significant at $P<0.05$. All data are expressed as the mean \pm standard error (S.E.).

\section{Results}

\section{Analysis of $L-P R L R$ and $S-P R L R$ and their associated gene sequences}


$\mathrm{KD}$, respectively, and the isoelectric points are 5.12 and 8.34 , respectively.

The nucleotide sequence similarity of the CDS region between ovis and other species of $L$ genes are highly conserved among ruminants.

protein structure of $L-P R L R$ includes alpha helix, extended strand, random coils and $\beta$-turns at proportions of $16.01 \%, 21 \%, 59.55 \%$ and $3.44 \%$, respectively, whereas the secondary protein structure of $S-P R L R$ contains only alpha helices, extended strand and random coils, at proportions of $18.24 \%, 30.07 \%$ and $48.99 \%$, respectively. The tertiary structures of $L-P R L R$ and $S$-PRLR encoding proteins are mainly composed of extended fragments and random coils

The mRNA expression of $L-P R L R$ and $S-P R L R$ in uterus, mammary gland, ovary, spleen

and lymph tissue during lactation and post-weaning periods are shown in Figure 2 and Table 2.

The mRNA expression of $L-P R L R$ in uterus, mammary gland, ovary, spleen and lymph tissue during lactation and post-weaning periods in ewes are shown in Table 2. During lactation mRNA expression of $L-P R L R$ was higher in the uterus than in the ovary, mammary gland and spleen $(P<0.05)$ but was similar to that of lymph tissue. However, during the post-weaning 
169

170

171

172

173

174

175

176

177

178

179

180

181

182

183

184

185

186

187

188

189

period, mRNA expression of $L-P R L R$ in the uterus was higher than that in lymph tissue

$(P<0.05)$, but it was not different from the values measured in the uterus, ovary, spleen and

mammary gland. The expression in lymph tissue was higher during lactation than in the post-

weaning period $(P<0.01)$ but there were no period-related differences in expression in the case of uterus, ovary, mammary gland or spleen.

The mRNA of S-PRLR in uterus, mammary gland, ovary, spleen and lymph tissue during lactation and post-weaning periods in ewes are shown in Table 2. There were no differences in mRNA expression of $S-P R L R$ among the five tissues during the lactation period. However, during the post-weaning period mRNA expression of $S-P R L R$ in uterus was higher than in the ovary and spleen $(P<0.05)$, although it was similar to that of the mammary gland and lymph tissue. No differences were observed in the mRNA expression of $S$ - $P R L R$ among ovary, mammary gland, spleen and lymph tissue during post-weaning period. Expression of S-PRLR in the uterus and mammary gland was lower during lactation than in the post-weaning period $(P<0.01)$, but there were no period-related differences in the cases of ovary, spleen or lymph tissue.

The expression of $L-P R L R$ and $S-P R L R$ in 5 tissue during the lactation and post-weaning period are shown in Figure 2. Expression of $L-P R L R$ in the uterus was higher than that of $S$ $P R L R$ during the lactation period $(P<0.01)$. However, there were no differences in expression of the two genes in the ovary, spleen, mammary gland and lymph tissue during the lactation period nor within any of the five tissues during the post-weaning period.

\section{Discussion}


190

191

192

193

194

195

196

197

198

199

200

201

202

203

204

205

206

207

208

209

210

\section{Sequence analysis of prolactin receptor isoforms}

A long form $(L-P R L R)$, an intermediate form $(I-P R L R)$ and two short forms $(S-P R L R)$ occur in humans (Trott et al., 2003; Abramicheva and Smirnova, 2019). There are at least four PRLR isoforms in mice, including three short and one long, but only two of the short PRLR isoforms are considered to be proteins (Tan et al., 2011) and there are two PRLR isoforms (L-PRLR and $S$ $P R L R)$ in rats (Jiang et al., 2004). Cloning and genomic analysis of cDNA has revealed that $L$ $P R L R$ and $S$-PRLR have arisen from the process of differential alternative splicing of their coding genes (Moore and Oka, 1993). S-PRLR differs from L-PRLR by having a 39 base pair insert at the beginning of the cytoplasmic domain, but it has two contiguous inframe stop codons at its 3' end (Bignon et al., 1997). The present study also reveals differences in the secondary and tertiary structure of the two forms of the receptor protein, which is consistent with there being differences in expression and function of the two protein forms. Our study also showed that the nucleotide sequences of $L-P R L R$ and $S$ - $P R L R$ genes in the sheep were similar to those of other species, indicating that these are highly conserved among ruminants, and could explain why $L$ $P R L R$ and $S$-PRLR have similar functions across different species.

\section{The expression of prolactin receptor isoforms in different tissues}

$L-P R L R$ has been reported as predominantly expressed in the mammary gland, ovary, liver, uterus, skeletal muscle, corpus luteum, and adrenal glands of goats (Shi et al., 2016). This is in keeping with the important role of prolactin receptors as the mediators of prolactin's actions in

processes such as growth, lactation, reproduction and immunity (Posner et al., 1974). Our results confirm the presence of $L-P R L R$ and $S-P R L R$ in tissue from the uterus, mammary gland, ovary, 
211 spleen and a lymph tissue in ewes during lactation and the post-weaning period. However, we

212 have found some differences in mRNA expression of $L-P R L R$ and $S$ - $P R L R$ throughout these

213 tissues in sheep. For instance, the high level of expression of $P R L R$ we recorded in the sheep

214 uterus in both periods that were sampled here accords with a similar finding in black Muscovy

215 ducks (Li et al., 2020). Prolactin probably has a vital role in the post-lambing regeneration of the

216 uterine epithelium, which is generally completed within 31 days (O'Shea and Wright, 1984). This

217 process involves reduction of the uterine volume, some tissue degradation, and epithelial repair

218 of the endometrium (Tielgy et al., 1982). The higher mRNA expression of $L-P R L R$ in uterine

219 tissue of the ewes, compared with that of $S-P R L R$, during lactation and post-weaning indicates

220

221

222

223

224

225

226

227

228

229

230

231

that the long isoform of the receptor may be primarily involved in uterine repair and recovery

following birth of lambs. The increase in expression of $S-P R L R$ in the uterus from lactation to

post-weaning indicates that the short form of the receptor may have a primary role during normal

maintenance of the uterus.

$L-P R L R$ and $S-P R L R$ appear to serve different roles in ovary as well. For example, PMSG increased mRNA expression of $L-P R L R$, suggesting a possible involvement of $L-P R L R$ in folliculogenesis. In contrast, hCG treatment stimulated expression of $S$ - $P R L R$, indicating a role for the corresponding receptor isoform in formation and maintenance of the corpus luteum (Thompson et al., 2011). Also, reverse-transcription PCR analysis of sheep ovarian tissue showed differences in localization and expression of both $S-P R L R$ and $L-P R L R$ throughout the estrous cycle, with $L$ PRLR being particularly localized in stromal cells surrounding primordial and primary follicles, whereas genes for both $P R L R$ isoforms were found in granulosa cells of preantral follicles and 
232 luteal cells within the corpus luteum (Picazo et al., 2004). The expression of $L-P R L R$ in the sheep

233 ovary is markedly increased around the time of estrus, unlike that of $S-P R L R$ which does not differ

234 throughout the estrous cycle (Picazo et al., 2004). However, during the lactation period follicle

235 development is inhibited and estrus does not occur (Song et al., 2019). In the case of $L-P R L R$ our

236 results show an increased level of expression during the post-weaning period which is consistent

237 with a role for the long form of the receptor during the recovery of ovarian follicular development

238 following the birth of lambs.

239 In goats, expression of $P R L R$ gradually increases during the dry period after lactation (Song

240 et al., 2019) in a pattern similar to the increases in expression levels of $L-P R L R$ and $S-P R L R$

241 recorded in the mammary glands of ewes in the present study. At the end of lactation mammary

242 glands enter a degenerative phase, in which the fat pad regenerates in concert with increases in

243 PRLR mRNA content of the adipocytes (Lesueur et al., 1991). This finding and the present

244 results implicate involvement of $\underline{L-P R L R}$ and $S-P R L R$ in the process of post-lactational

mammary remodeling. $L-P R L R$ has a principal role in the induction of milk protein gene

transcription (Das and Vonderhaar, 1995) whereas the involvement of $S$-PRLR is less clear. For

instance, $L-P R L R$ could activate the $\beta$-casein gene promoter, while $S$ - $P R L R$ did not (Berlanga et

al., 1997). Also, over-expression of $S-P R L R$ enabled mammary development and function when

PRLR genes were knocked out in heterozygous mice (Zi et al., 2012) and S-PRLR appears to

have a negative role in relation to the involvement of PRL in milk protein gene transcription

251 (Berlanga et al., 1997). Together with the present finding of higher expression of $L-P R L R$ 
253 the predominant role on the maintenance of lactation and in mammary gland repair processes.

254 PRL play an crucial role in regulating immunity (Gharbaran et al., 2020), not only by

255 promoting the proliferation of immune cells, but also by stimulating the production of antibodies

256 such as IgG and IgM, and these functions involve expression of the PRL receptor genes (Zhou et

257 al., 2020). For instance, the transcripts encoding both isoforms of PRLR (L-PRLR and S-PRLR)

258 were recorded in all lymphoid tissues examined in mice and rats (Touraine et al., 1995) and in the

259 spleens and lymph tissues of sheep in our study. In the case of thymus and spleen, mRNA

260 expression of $L-P R L R$ was higher than that of $S-P R L R$ (Ouhtit et al., 1994). In the present study,

261 expression of $L-P R L R$ was higher than that of $S-P R L R$ in lymphatic tissue during lactation, but

262

263

264

265

266

267

268

269

270

271

272

273

this pattern reversed during the post-weaning period. These differential findings indicate different

specific roles for the two isoforms of the receptor in relation to their involvement in the progression

of immune responses during and after lactation that warrant further study.

\section{Conclusions}

It concluded that the mRNA expression of $L-P R L R$ and $S$ - $P R L R$ genes varies among

different tissues in sheep. The mRNA expression of $L-P R L R$ and $S$ - $P R L R$ is higher in the uterus than in the ovary, spleen, mammary gland and lymph tissue during both lactation and the postweaning period. The mRNA expression of $L-P R L R$ is higher than $S$ - $P R L R$ in the uterus, ovary, spleen, mammary gland during both lactation and post-weaning period. The mRNA expression of $L-P R L R$ was higher than $S-P R L R$ in lymph tissue during lactation, but this pattern reversed during the post-weaning period. 


\section{Acknowledgements}

The authors express their gratitude to Doctor Zhang for laboratory support and to fellow

277 students in the laboratory for assistance.

278

279

280

281

282

283

284

285

286

287

288

289

290

291

292

293

294

\section{References}

Abramicheva PA, Smirnova OV. 2019. Prolactin Receptor Isoforms as the Basis of Tissue-

Specific Action of Prolactin in the Norm and Pathology. Biochemistry-Moscow 84(4): 329-345

DOI: $10.1134 / \mathrm{S} 0006297919040011$.

Berlanga JJ, GarciaRuiz JP, PerrotApplanat M, Kelly PA, Edery M. 1997. Short form of the prolactin (PRL) receptor silences PRL induction of the beta-casein gene. Molecular

Endocrinology 11(10): 1449-1457 DOI: 10.1210/me.11.10.1449.

Bernichtein S, Touraine P, Goffin V. 2010. New concepts in prolactin biology. Journal of

Endocrinology 206(1): 1-11 DOI: 10.1677/JOE-10-0069.

Bignon, C, Binart, N, Ormandy, C, Schuler, LA, Kelly, PA, Djiane, J. 1997. Long and short forms of the ovine prolactin receptor: cDNA cloning and genomic analysis reveal that the two forms arise by different alternative splicing mechanisms in ruminants and in rodents. Journal of Molecular Endocrinology 19(2): 109-120 DOI: 10.1677/jme.0.0190109.

Boutin JM, Jolicoeur C, Okamura H, Gagnon J, Edery M, Shirota M, Banville D, Dusanter-Fourt I, Djiane J, Kelly PA. 1988. Cloning and expression of the rat prolactin receptor, a member of the growth hormone/prolactin receptor gene family. Cell 53(1): 69-77 DOI:10.1016/00928674(88)90488-6. 
295 Chang LF, Karin M. 2001. Mammalian MAP kinase signalling cascades. Nature 410(6824): 37 -

29640 DOI: $10.1038 / 35065000$.

297 Chen YX, Moutal A, Navratilova E, Kopruszinski C, Yue X, Ikegami M, Chow M, Kanazawa I,

Bellampalli SS, Xie J, Patwardhan A, Rice K, Fields H, Akopian A, Neugebauer V, Dodick D,

Khanna R, Porreca F. 2020. The prolactin receptor long isoform regulates nociceptor sensitization and opioid-induced hyperalgesia selectively in females. Science Translational

Medicine 12(529) DOI: 10.1126/scitranslmed.aay7550.

302

Clarke DL, Arey BJ, Linzer DI. 1993. Prolactin receptor messenger ribonucleic acid expression 303 in the ovary during the rat estrous cycle. Endocrinology 133(6): 2594-2603 DOI:10.1210/en.133.6.2594.

Clarke DL, Linzer DIH. 1993. Changes in prolactin receptor expression during pregnancy in the 306 mouse ovary. Endocrinology 133(1): 224-232 DOI:10.1210/en.133.1.224.

Das R, Vonderhaar BK. 1995. Transduction of prolactin (PRL) growth signal through both long and short forms of the PRL receptor. Molecular Endocrinology 9(12): 1750-1759

DOI: $10.1210 / \mathrm{me} .9 .12 .1750$.

Freeman ME, Kanyicska B, Lerant A, Nagy G. 2000. Prolactin: structure, function, and regulation of secretion. Physiological Reviews 80(4): 1523-1631.

Gharbaran R, Onwumere O, Codrington N, Somenarain L, Redenti S. 2020.

Immunohistochemical localization of prolactin receptor (PRLR) to Hodgkin's and Reed- 
316 Goffin V, Bouchard B, Ormandy CJ, Weimann E, Ferrag F, Touraine P, Bole-Feysot C,

317 Maaskant RA, Clement-Lacroix P, Edery M, Binart N, Kelly PA. 1998. Prolactin: A hormone at

318 the crossroads of neuroimmunoendocrinology. Annals of the New York Academy of Sciences

319 840(1): 498-509 DOI: 10.1111/j.1749-6632.1998.tb09588.x.

320 Goffin V, Shiverick KT, Kelly PA, Martial JA. 1996. Sequence-function relationships within the expanding family of prolactin, growth hormone, placental lactogen, and related proteins in

mammals. Endocrine Reviews 17(4): 385-410 DOI: 10.1210/er.17.4.385.

Jiang R, Li J, Qu L, Li H, Yang N. 2004. A new single nucleotide polymorphism in the chicken

pituitary-specific transcription factor (POU1F1) gene associated with growth rate. Animal

Genetics 35(4): 344-346 DOI: 10.1111/j.1365-2052.2004.01164.x.

Lesueur L, Edery M, Ali S, Paly J, Kelly PA, Djiane J. 1991. Comparison of long and short

forms of the prolactin receptor on prolactin-induced milk protein gene transcription. Proceedings

of the National Academy of Sciences of the United States of America 88(3): 824-828

DOI:10.1073/pnas.88.3.824.

Li X, Ji W, Sun G, Xiao W, Bian Y, Qing H. 2020. Cloning and expression analysis of PRL and

PRLR genes in black Muscovy duck. British Poultry Science 61(1): 92-96

DOI: $10.1080 / 00071668.2019 .1680800$.

Moore RC, Oka T. 1993. Cloning and sequencing of the cDNA encoding the murine mammary gland long-form prolactin receptor. Gene 134(2): 263-265 DOI:10.1016/0378-1119(93)90104-B. 
337 cancer patients. Annals of Diagnostic Pathology 46 DOI: 10.1016/j.anndiagpath.2020.151507.

338 O'Shea JD, Wright PJ. 1984. Involution and regeneration of the endometrium following

339 parturition in the ewe. Cell and Tissue Research 236(2): 477-485.

340 Ouhtit A, Kelly PA, Morel G. 1994. Visualization of gene expression of short and long forms of

341 prolactin receptor in rat digestive tissues. The American Journal of Physiology 266(5): G807-

342815.

343 Picazo RA, Ruiz JPG, Moreno JS, de Bulnes AG, Munoz J, Silvan G, Lorenzo PL, Illera JC.

344 2004. Cellular localization and changes in expression of prolactin receptor isoforms in sheep

345 ovary throughout the estrous cycle. Reproduction 128(5): 545-553 DOI: 10.1530/rep.1.00343.

346 Posner BI, Kelly PA, Shiu RP, Friesen HG. 1974. Studies of insulin, growth hormone and

347 prolactin binding: tissue distribution, species variation and characterization. Endocrinology

348 95(2): 521-531 DOI:10.1210/endo-95-2-521.

349 Shi HP, Zhang TY, Yi YQ, Wang H, Luo J. 2016. Long form PRLR (IPRLR) regulates genes

involved in the triacylglycerol synthesis in goat mammary gland epithelial cells. Small Ruminant

Research 139: 7-14 DOI: 10.1016/j.smallrumres.2016.04.008.

Song YX, Hu P, Bai YL, Zhao C, Xia C, Xu C. 2019. Plasma metabolic characterisation of dairy

cows with inactive ovaries and oestrus during the peak of lactation. Journal of Veterinary

Research 63(3): 359-367 DOI: 10.2478/jvetres-2019-0047.

Tan DY, Chen KHE, Khoo T, Walker AM. 2011. Prolactin increases survival and migration of 
358

359

360

361

362

363

364

365

366

367

368

369

370

371

372

373

374

375

376

377

378

DOI: 10.1016/j.canlet.2011.06.014.

Thompson IM, Ozawa M, Bubolz JW, Yang Q, Dahl GE. 2011. Bovine luteal prolactin receptor expression: Potential involvement in regulation of progesterone during the estrous cycle and pregnancy. Journal of Animal Science 89(5): 1338-1346 DOI: 10.2527/jas.2010-3559.

Tielgy AH, Fathalla M, Omar MA, Al-Dahash S. 1982. The Clinical and Morphological

Characteristics of the Uterus of the Goat during the Period of Involution. The Canadian

Veterinary Journal 23(4): 138-140.

Touraine P, Kelly PA. 1995. Expression of the short and long forms of the prolactin receptor in

Murine lymphoid-tissues. Recent Progress in Hormone Research 50: 423-428.

Trott JF, Hovey RC, Koduri S, Vonderhaar BK. 2003. Alternative splicing to exon 11 of human prolactin receptor gene results in multiple isoforms including a secreted prolactin-binding protein. Journal of Molecular Endocrinology 30(1): 31-47 DOI: 10.1677/jme.0.0300031.

Viitala S, Szyda J, Blott S, Schulman N, Lidauer M, Maki-Tanila A, George M, Vilkki J. 2006.

The role of the bovine growth hormone receptor and prolactin receptor genes in milk, fat and

protein production in Finnish Ayrshire dairy cattle. Genetics 173(4): 2151-2164

DOI: 10.1534/genetics.105.046730.

Zhou YX, Zong HF, Han L, XIE YQ, Jiang H, Gilly J, Zhang BH, Lu HL, Chen J, Sun R, Pan

ZD, Zhu JW. 2020. A novel bispecific antibody targeting CD3 and prolactin receptor (PRLR)

against PRLR-expression breast cancer. Journal of Experimental \& Clinical Cancer Research

39(7528): 667-674 DOI: 10.1186/s13046-020-01564-4.

Zi XD, Chen DW, Wang HM. 2012. Molecular characterization, mRNA expression of prolactin

PeerJ reviewing PDF | (2021:02:58076:2:0:CHECK 28 Jun 2021) 
379 receptor (PRLR) gene during pregnancy, nonpregnancy in the yak (Bos grunniens). General and 380 Comparative Endocrinology 175(3): 384-388 DOI: 10.1016/j.ygcen.2011.12.004.

381

382

383 
Figure 1

Prediction of tertiary structure of L-PRLR and S-PRLR protein in sheep

Prediction of tertiary structure of L-PRLR and S-PRLR protein in sheep 

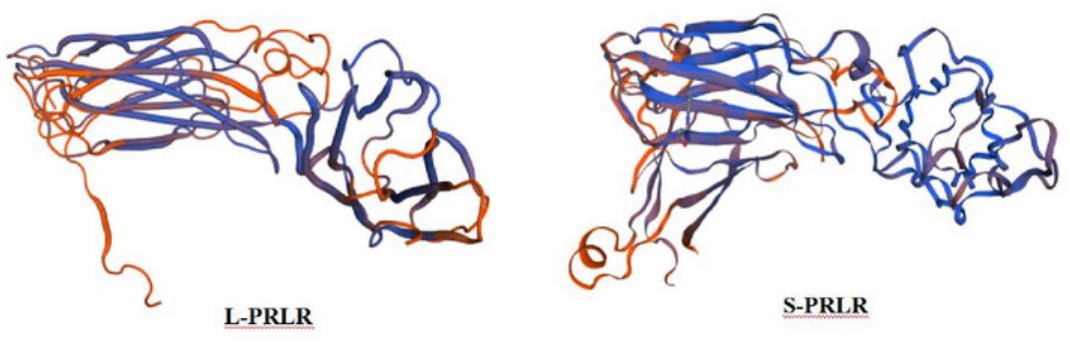
Figure 2

mRNA expression of $L-P R L R$ and $S-P R L R$ in different tissues during lactation and postweaning in sheep.

** indicates that the difference is extremely significant $\square \mathrm{P}<0.01 \square$. 

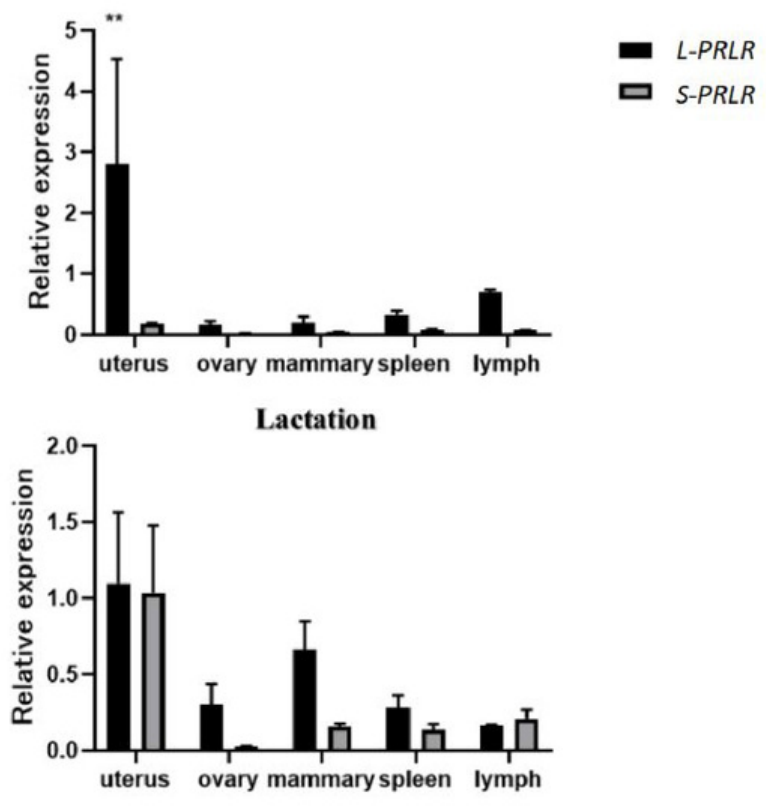

Post-weaning

Figure 2 mRNA expression of $L-P R L R$ and $S$-PRLR in different tissues during lactation and post-weaning in sheep.

** indicates that the difference is extremely significant $(\mathrm{P}<0.01)$. 


\section{Table $\mathbf{1}$ (on next page)}

The nucleotide sequence similarity of the CDS region of $L-P R L R$ and S-PRLR $\square \square$

The nucleotide sequence similarity of the CDS region of $L-P R L R$ and $S-P R L R \square \% \square$ 
1 Table 1 The nucleotide sequence similarity of the CDS region of $L-P R L R$ and $S-P R L R$ (\%) 2

\begin{tabular}{c|ccccc}
\hline Species & Capra hircus & Bos taurus & Sus scrofa & Mus musculus & Homo sapiens \\
& & & & & \\
\hline L-PRLR & 97.65 & 94.79 & 77.16 & 65.12 & 71.86 \\
S-PRLR & 98.88 & 96.18 & 85.20 & 16.70 & 65.16 \\
\hline
\end{tabular}




\section{Table 2 (on next page)}

Relative expression of $L-P R L R$ and $S-P R L R$ in different tissues during lactation and postweaning in sheep

Means with different superscripts within the same row are significantly different $(P<0.05)$; Asterisks (**) within the same column represent significant differences $(P<0.01)$. 
1 Table 2 Relative expression of $L-P R L R$ and $S$-PRLR in different tissues during lactation and

2

post-weaning in sheep

\begin{tabular}{ccccccc}
\hline & uterus & ovary & $\begin{array}{c}\text { mammary } \\
\text { gland }\end{array}$ & spleen & lymph tissue \\
\hline L-PRLR & Lactation & $2.808 \pm 1.725^{\mathrm{a}}$ & $0.164 \pm 0.064^{\mathrm{b}}$ & $0.194 \pm 0.102^{\mathrm{b}}$ & $0.330 \pm 0.065^{\mathrm{b}}$ & $0.700 \pm 0.045^{\mathrm{ab}^{* *}}$ \\
& Post-weaning & $1.098 \pm 0.465^{\mathrm{a}}$ & $0.305 \pm 0.134^{\mathrm{ab}}$ & $0.662 \pm 0.188^{\mathrm{ab}}$ & $0.282 \pm 0.079^{\mathrm{ab}}$ & $0.160 \pm 0.009^{\mathrm{b}}$ \\
& & & & & & \\
S-PRLR & Lactation & $0.186 \pm 0.007$ & $0.022 \pm 0.002$ & $0.038 \pm 0.004$ & $0.076 \pm 0.014$ & $0.072 \pm 0.002$ \\
& & & & $0.156 \pm 0.020^{\mathrm{ab}}$ & $0.138 \pm 0.035^{\mathrm{b}}$ & $0.208 \pm 0.060^{\mathrm{ab}}$ \\
\hline
\end{tabular}

3 Means with different superscripts within the same row are significantly different $(\mathrm{P}<0.05)$; Asterisks $(* *)$ within the same column 